\title{
Biohydrogen Production From Agro-industrial Wastes Using Clostridium Beijerinckii and Isolated Bacteria as Inoculum
}

\section{Walter José Martinez-Burgos}

Universidade Federal do Paraná - Campus Centro Politécnico: Universidade Federal do Parana - Campus Centro Politecnico

\section{Jair Rosário do Nascimento Junior}

Universidade Federal do Paraná - Campus Centro Politécnico: Universidade Federal do Parana - Campus Centro Politecnico

Adriane Bianchi Pedroni Medeiros ( $\nabla$ adrianebpm@ufpr.br)

Universidade Federal do Paraná - Campus Centro Politécnico: Universidade Federal do Parana - Campus

Centro Politecnico https://orcid.org/0000-0002-8804-0407

\section{Leonardo Wedderhoff Herrmann}

Universidade Federal do Paraná - Campus Centro Politécnico: Universidade Federal do Parana - Campus

Centro Politecnico

\section{Eduardo Bittencourt Sydney}

Federal Technological University of Paraná: Universidade Tecnologica Federal do Parana

\section{Carlos Ricardo Soccol}

Universidade Federal do Paraná - Campus Centro Politécnico: Universidade Federal do Parana - Campus Centro Politecnico

\section{Research Article}

Keywords: Biohydrogen, soft drink wastewater, corn steep liquor, cheese whey, bacteria

Posted Date: August 5th, 2021

DOl: https://doi.org/10.21203/rs.3.rs-769078/v1

License: (9) This work is licensed under a Creative Commons Attribution 4.0 International License. Read Full License

Version of Record: A version of this preprint was published at BioEnergy Research on November 15th, 2021. See the published version at https://doi.org/10.1007/s12155-021-10358-1. 


\section{Abstract}

The search for renewable and sustainable sources of energy has been one of the main goals of society in recent years, especially to reduce the environmental impacts of fossil fuels. One promising alternative is the production of hydrogen, which does not emit greenhouse gases and can be produced from agroindustrial wastes. The Clostridium genus is recorded as having high hydrogen yields compared to other genus, with several producing species. The objective of this work was to evaluate biohydrogen production potential of four agro-industrial residues, which were soft drink wastewater, corn steep liquor, cheese whey, and expired Guaraná soft drink, using one model strain Clostridium beijerinckii ATCC 8260 and newly isolated Clostridium butyricum DEBB-B348. The agro-industrial wastes were characterised in terms of monosaccharide, organic acid, amino acid, cation, and anion concentrations and compared to the literature. After performing subsequent experimental designs, the significant factors were cheese whey concentration, corn steep liquor concentration, and fermentation time for $C$. beijerinckii, and corn steep liquor concentration and fermentation time for $C$. butyricum ( $\mathrm{p} \leq 0.05)$, with an $\mathrm{R}^{2}$ of 0.950 and 0.895 , respectively. The maximum hydrogen volume production was $18.5 \pm 1.68 \mathrm{~mL}$ and $27.4 \pm 1.84 \mathrm{~mL}$ for each strain, respectively. The $C$. butyricum 16s rRNA gene phylogenetic tree and the carbohydrate, organic acid, and amino acid kinetics of the optimum medium are also presented. These results indicate a potential hydrogen production process utilising less expensive substrates, proposing more proper disposal for agro-industrial wastes and using an isolated strain with high yield.

\section{Introduction}

Alternative renewable energies are a transversal area that encompass many of the sustainable development goals, such as renewable energy, innovation and infrastructure, sustainable cities and communities, responsible consumption, climate action, and life on land. The unacceptable environmental impacts caused by the large use of fossil fuels have boosted research on sustainable biofuels with reduced environmental impacts [1]. Among the existing biofuels, hydrogen ("bioH ${ }_{2}$ ") stands out for not producing greenhouse gases during its combustion, for being produced from a variety of energy sources, for being safely stored and transported, and for being converted into electricity [2]. Hydrogen may play an important role in building a more sustainable society, especially in the transportation sector where $\mathrm{CO}_{2}$ capture from vehicles is virtually impossible.

The renewable production of hydrogen is derived from the dissociation of $\mathrm{H}_{2} \mathrm{O}$ (commercial technology), the thermochemical processing of biomass, and the anaerobic fermentation of organic raw materials. Fermentative hydrogen production (" $\mathrm{bioH}_{2}$ ") is generated under milder conditions and using (agro)industrial byproducts.

Several types of microorganisms are capable of producing biohydrogen, such as cyanobacteria (Synechocystis sp., Desertifilum sp., Synechococcus sp., Phormidium corium, Synechocystis sp., Oscillatoria sp., Anabaena sp.) [3], microalgae (Scenedesmus obliquus, Chlamydomonas reinhardtii, 
bacteria [1]. Producing genres involve Bacillus, Citrobacter, Enterobacter, Escherichia, and Rhodopseudomonas $[5,6]$. Clostridium deserves special attention due to the highest hydrogen yields when compared to other genera and its tendency to dominate dark fermentation in cases of co-culture [7]. Many species of this genus are capable of producing biohydrogen, such as $C$. acetobutylicum, $C$. butyricum, C. beijerinckii, and C. tyrobutyricum [8].

The use of agro-industrial residues as a substrate for $\mathrm{bioH}_{2}$ production significantly reduces the costs of production and provides more rational disposal for these wastes. Recent studies have proven that the use of substrates such as cassava processing wastewater, corn steep liquor (CSL), beverage wastewater, mushroom farm waste and others are suitable for biohydrogen production in significant quantities [912]. The possibility of using regional wastes for the production of a renewable source of energy has a great impact on local communities, economies, and the environment. The objective of this work was to evaluate the biohydrogen production potential of four agro-industrial residues (soft drink wastewater, corn steep liquor, cheese whey, and expired Guaraná soft drink) using one model strain of Clostridium beijerinckii (ATCC 8260) and newly isolated Clostridium butyricum (DEBB-B348).

\section{Materials And Methods}

\section{Physico-chemical characterisation of wastewaters}

Soft drink wastewater (SDW) and expired Guaraná were donated by the company Ambev (Almirante Tamandaré, Paraná, Brazil). Cheese whey (CW) was provided by the company Anila (Fernandes Pinheiro, Paraná, Brazil), and CSL was provided by the company Ingredion (Balsa Nova, Paraná, Brazil). The industrial wastewaters were stored at $-20^{\circ} \mathrm{C}$ until use.

Cations and anions were analysed by ion chromatography (761 Compact IC, Metrohm AG) using Metrosep C 3250/4.0 and Metrosep A Supp5 250/4.0 columns, respectively. For the quantification of cations, a mobile phase composed of $3.5 \mathrm{mM} \mathrm{HNO}_{3}$ at a flow rate of $0.9 \mathrm{~mL} \mathrm{~min}^{-1}$ was used, while for anions a mobile phase containing $3.2 \mathrm{mM} \mathrm{Na}_{2} \mathrm{CO}_{3}$ and $1.0 \mathrm{mM} \mathrm{NaHCO}_{3}$ at a flow rate of $0.7 \mathrm{~mL} \mathrm{~min}^{-1}$ was used. Run times were 25 and 30 min, respectively.

The determination of the chemical oxygen demand (COD) and the total nitrogen content were done using Standard Methods for the Examination of Water and Wastewater 1992 [13].

The free amino acid content of CSL and CW was analysed by an automated SYKAM S433 amino acid analyser (Eresing, Germany) using the ninhydrin method. Three solutions were used in the identification reactions: buffer $A, B$, and a regeneration solution. Buffer A was composed of tri-sodium citrate dihydrate, citric acid, methanole, hydrochloric acid, and phenol. Buffer B was of composed of tri-sodium citrate dihydrate, sodium hydroxide, and boric acid, and the regeneration solution was composed of sodium hydroxide and boric acid. The operating conditions were the following: the flow rates in the gradient and 
in the reactor was $130^{\circ} \mathrm{C}$. This method was also used to determine the amino acid kinetics during the fermentation of the best bio $\mathrm{H}_{2}$ production condition.

\section{Inoculum}

Clostridium beijerinckii ATCC 8260 and an isolated strain from a consortium obtained from sugarcane cultivation soil (LPBAH3) [14] were first compared for their ability to produce biohydrogen from a combination of the industrial wastewaters. Isolation was carried by successive cultivation in Man, Rogosa, \& Sharpe (MRS) medium by the pour plate method and incubation in an anaerobic jar. Upon isolation, the strain was submitted to identification. The 16S rRNA gene sequences of the reference strains retrieved from NCBI (National Center for Biotechnology Information, MA, USA) were aligned using the online version of MAFFT program, version 7, with the option Auto (FFT-NS-1, FFT-NS-2, FFT-NS-i or LINS-i). A neighbour-joining phylogenetic tree was constructed using the MEGA X 10.1 computer [15] based on the MSA file by MAFFT. The evolutionary distances were computed by the maximum composite likelihood method [16] and maximum-parsimony [17]. The robustness of individual branches was estimated by bootstrapping with 1000 replicates [18]. The isolated strain was identified as Clostridium butyricum (DEBB-B348). Clostridium beijerinckii and Clostridium butyricum (DEBB-B348) were kept in a medium composed of soft drink wastewater containing $3 \% \mathrm{CSL}(\mathrm{v} / \mathrm{v})$. The $\mathrm{pH}$ of the medium was adjusted to 7.0 using $35 \% \mathrm{NaOH}$ solution. Procedures according to Balch et al. [19] were adopted to guarantee an anaerobic environment. Oxygen was removed from the medium by boiling $\left(100-105^{\circ} \mathrm{C}\right)$ under anoxic conditions under an argon atmosphere. Reduction of redox potential was ensured by the addition of $\mathrm{NaHCO}_{3}\left(1.0 \mathrm{~g} \mathrm{~L}^{-1}\right)$ and Cysteine- $\mathrm{HCl}\left(0.5 \mathrm{~g} \mathrm{~L}^{-1}\right)$ at $85^{\circ} \mathrm{C}$ and $65^{\circ} \mathrm{C}$, respectively (for inoculants only). All experiments were carried in Hungate tubes with a working volume of $6 \mathrm{~mL}$ and a total volume $16 \mathrm{~mL}$. The tubes were sealed with bakelite caps and autoclavable rubber stoppers. To keep the strains active, they were subcultured weekly by transferring $1 \mathrm{~mL}$ of inoculum to fresh medium and incubated at $37^{\circ} \mathrm{C}$.

\section{Experimental Design, Optimisation, And Statistical Analyses}

A Plackett-Burman design for six parameters with a total of 12 runs was used for each strain. The parameters studied were (i) glucose $0-5 \mathrm{~g} \mathrm{~L}^{-1}$, (ii) fermentation time 24-48 h, (iii) expired soft drink 0$20 \%(\mathrm{v} / \mathrm{v})$, (iv) inoculum 10-20\%, (v) corn steep liquor 0-10\% (v/v), and (vi) cheese whey $0-40 \%(\mathrm{v} / \mathrm{v})$. The Pareto diagram was used to determine the effects of significance in the experiments performed.

Upon significant effects determination, Box-Behnken design and rotational central composite design (RCCD) were carried for Clostridium beijerinckii ATCC 8260 and Clostridium butyricum DAEBB-B348, respectively (Table 1). The Box-Behnken design contained 3 factors, 3 central points, and 15 runs; RCCD contained 2 factors, with 5 central points, 4 axial points, and 13 runs. The statistical analyses were performed using Minitab software. The optimisation provided an adjusted quadratic model Eq. 1 shown below. 
Table 1

Rotational central composite design (RCCD) and the Box-Behnken planning matrix.

\begin{tabular}{|c|c|c|c|c|c|c|c|c|}
\hline \multicolumn{5}{|c|}{ Clostridium beijerinckii (Box-Behnken) } & \multicolumn{4}{|c|}{ Clostridium butyricum (RCCD) } \\
\hline \multirow[t]{2}{*}{ Run } & $\% C S L$ & $t(h)$ & $\% \mathrm{CW}$ & $\mathrm{VH}_{2}$ & & & & \\
\hline & $\begin{array}{l}\text { (Real } \\
\text { value) }\end{array}$ & $\begin{array}{l}\text { (Real } \\
\text { value) }\end{array}$ & $\begin{array}{l}\text { (Real } \\
\text { value) }\end{array}$ & & & & & \\
\hline 1 & $-1(6)$ & $1(48)$ & $0(40)$ & 4.87 & & & & \\
\hline 2 & $0(10)$ & $0(36)$ & $0(40)$ & 11.35 & Run & $\%$ CSL & $t(h)$ & $\mathrm{VH}_{2}$ \\
\hline & & & & & & $\begin{array}{l}\text { (Real } \\
\text { value) }\end{array}$ & (Real value) & $(\mathrm{mL})$ \\
\hline 3 & 1014 & $0(36)$ & $-1(35)$ & 13.23 & 1 & $1(14)$ & $-1(24)$ & 15.5 \\
\hline 4 & $-1(4.34)$ & $0(36)$ & $-1(35)$ & 7.65 & 2 & $0(10)$ & $-1.41(19.029)$ & 15.3 \\
\hline 5 & $1(14)$ & $-1(24)$ & $0(40)$ & 5.91 & 3 & $-1(6)$ & $1(48)$ & 16.7 \\
\hline 6 & $0(10)$ & $-1(24)$ & $-1(35)$ & 6.90 & 4 & $0(10)$ & $0(36)$ & 19.9 \\
\hline 7 & $0(10)$ & $1(48)$ & $-1(35)$ & 12.95 & 5 & $0(10)$ & $0(36)$ & 20.5 \\
\hline 8 & $1(14)$ & $0(36)$ & $1(45)$ & 16.41 & 6 & $0(10)$ & $0(36)$ & 21.5 \\
\hline 9 & $0(10)$ & $1(48)$ & $1(45)$ & 10.32 & 7 & $-1.41(4.34)$ & $0(36)$ & 13.17 \\
\hline 10 & $-1(6)$ & $-1(24)$ & $0(40)$ & 3.78 & 8 & $1.41(15.65)$ & $0(36)$ & 21.9 \\
\hline 11 & $0(10)$ & $-1(24)$ & $1(45)$ & 8.10 & 9 & $1(14)$ & $1(48)$ & 22.3 \\
\hline 12 & $-1(6)$ & $0(36)$ & $1(45)$ & 6.86 & 10 & $-1(6)$ & $-1(24)$ & 8.23 \\
\hline 13 & $0(10)$ & $0(36)$ & $0(40)$ & 12.33 & 11 & $0(10)$ & $0(36)$ & 22.34 \\
\hline 14 & $0(10)$ & $0(36)$ & $0(40)$ & 12.22 & 12 & $0(10)$ & $1.41(52.97)$ & 25.9 \\
\hline 15 & $1(10)$ & $1(48)$ & $0(40)$ & 17.14 & 13 & $0(10)$ & $0(36)$ & 20.05 \\
\hline
\end{tabular}

$H 2=\beta o+\sum_{i=1}^{k} \beta i X i+\sum_{i=1}^{k} \beta i i X i X i+\sum_{i=1} K-1+\sum_{j=1+i}^{k} \beta i j X i X j$ (Eq. 1)

\section{Kinetics Of Bioh And Volatile Fatty Acids}

The kinetics of hydrogen and volatile fatty acid production were carried out in optimised media under anaerobic conditions. All experiments were conducted in Hungate tubes with a working volume of $6 \mathrm{~mL}$ that were sealed with bakelite caps and autoclavable rubber stoppers. The $\mathrm{pH}$ of the medium was adjusted to 7.0 using $35 \% \mathrm{NaOH}$ solution. The inoculum rate was $10 \%$, and the temperature of incubation was $37^{\circ} \mathrm{C}$. 
Quantification of hydrogen production and volatile fatty acids was carried periodically at $8 \mathrm{~h}$ and $16 \mathrm{~h}$ intervals for Clostridium butyricum and Clostridium beijerinckii, respectively. A glass syringe was used to collect the produced gas, which was analysed in a 490 Micro GC System gas chromatograph (Agilent) equipped with two columns (Molsieve $5 \AA$ and PoraPLOT U) and a thermal conductivity detector (TCD). In the Molsieve $5 \AA$ column, the injection temperature was $110^{\circ} \mathrm{C}$, with an injection time of $20 \mathrm{~ms}$, column temperature of $90^{\circ} \mathrm{C}$, and an initial pressure of $190 \mathrm{kPa}$. In the PoraPLOT U (PPU) column, the injection temperature was $110^{\circ} \mathrm{C}$, with a column temperature of $90^{\circ} \mathrm{C}$ and an initial pressure of $150 \mathrm{kPa}$. The time for each run was $1.2 \mathrm{~min}$. The mobile phase used was argon gas with a purity of $99.999 \%$.

The qualitative and quantitative analysis of volatile fatty acids and substrate consumption were carried in a HPLC Agilent 1260 Infinity Quaternary LC with RI detector and Hi-Plex-H column. The detector and column temperature were $50^{\circ} \mathrm{C}$ and $60^{\circ} \mathrm{C}$, respectively. The mobile phase used was $5 \mathrm{mM} \mathrm{H}_{2} \mathrm{SO}_{4}$ at a flow rate of $0.6 \mathrm{~mL} \mathrm{~min}^{-1}$, and the injection volume was $10 \mu \mathrm{L}$. Prior to injection $(1 \mathrm{~mL})$, the liquid samples were submitted to centrifugation at $6000 \mathrm{rpm}$ for $10 \mathrm{~min}$ and microfiltration in cellulose acetate membranes $(0.22 \mu \mathrm{m})$.

\section{Results And Discussion}

\section{Physicochemical characterisation of effluents}

The physicochemical composition of the three studied agro-industrial residues (CSL, SDW, and CW) was different in terms of carbohydrates, organic acids, nitrogen, cations, and anions (Table 2). The expired refrigerant "Guaraná" was not characterised since it was not significant. The CW was the only waste that presented lactose in detectable quantities $\left(4.55 \mathrm{~g} \mathrm{~L}^{-1}\right)$, while glucose, fructose, and maltose were undetectable. Similar results has been documented in whey used for hydrogen production by Escherichia coli, but with a higher content of lactose $\left(15 \mathrm{~g} \mathrm{~L}^{-1}\right)[20,21]$. Both CSL and soft drink wastewater contained glucose and fructose; however, CSL exhibited much higher concentrations (> $35 \mathrm{~g} \mathrm{~L}^{-1}$ for each carbohydrate, versus 0.7 and $3.98 \mathrm{~g} \mathrm{~L}^{-1}$ of glucose and fructose, respectively, in SDW). The CSL used in this study is richer in the cited carbohydrates than the used by Martinez-Burgos et al. (2021b) for the production of $\mathrm{bioH}_{2}$. It is important to highlight that CSL also presented an elevated concentration of lactic acid (92.5 $\left.\mathrm{g} \mathrm{L}^{-1}\right)$ which can be used as a second carbon source for some lactic acid bacteria and species of the Clostridium genus [23, 24]. 
Table 2

Physicochemical characterisation of corn steep liquor, soft drink wastewater, and cheese whey.

\begin{tabular}{|c|c|c|c|c|c|c|}
\hline Substance & CSL & SDW & CW & Substance & CSL & CW \\
\hline Glucose $\left(\mathrm{g} \mathrm{L}^{-1}\right)$ & 36.31 & 0.7 & - & \multirow{2}{*}{$\begin{array}{l}\text { Thr }(\mu \mathrm{mol} \mathrm{mL}- \\
\text { 1) }\end{array}$} & \multirow[t]{2}{*}{$147 \pm 12$} & \multirow[t]{2}{*}{$75 \pm 12.5$} \\
\hline Fructose $\left(\mathrm{g} \mathrm{L}^{-1}\right)$ & 35.49 & 3.998 & - & & & \\
\hline Maltose $\left(\mathrm{g} \mathrm{L}^{-1}\right)$ & 1.493 & - & - & \multirow{2}{*}{$\begin{array}{l}\text { Cys ( } \mu \mathrm{mol} \mathrm{mL}{ }^{-} \\
1 \text { ) }\end{array}$} & \multirow{2}{*}{$\begin{array}{l}116.4 \pm \\
18.0\end{array}$} & \multirow[t]{2}{*}{$35 \pm 14.8$} \\
\hline Lactose $\left(\mathrm{g} \mathrm{L}^{-1}\right)$ & - & - & 4.55 & & & \\
\hline Lactic Acid $\left(\mathrm{g} \mathrm{L}^{-1}\right)$ & 92.55 & 0.5676 & - & \multirow{2}{*}{$\begin{array}{l}\text { Val }(\mu \mathrm{mol} \mathrm{mL}- \\
\left.{ }^{-}\right)\end{array}$} & \multirow{2}{*}{$\begin{array}{l}135.3 \pm \\
22.9\end{array}$} & \multirow[t]{2}{*}{$58.8 \pm 5.4$} \\
\hline Citric Acid $\left(\mathrm{g} \mathrm{L}^{-1}\right)$ & - & 1.182 & - & & & \\
\hline Acetic Acid $\left(\mathrm{g} \mathrm{L}^{-1}\right)$ & 0.3617 & 0.3071 & - & \multirow{2}{*}{$\begin{array}{l}\text { Met }(\mu \mathrm{mol} \mathrm{mL}- \\
\left.{ }^{1}\right)\end{array}$} & \multirow{2}{*}{$\begin{array}{l}211.8 \pm \\
28.4\end{array}$} & \multirow[t]{2}{*}{$15 \pm 7.4$} \\
\hline Total nitrogen $\left(\mathrm{g} \mathrm{L}^{-1}\right)$ & 10.8 & 0.5 & 3.6 & & & \\
\hline $\begin{array}{l}\text { Phosphorus } \mathrm{P}_{2} \mathrm{O}_{5}\left(\mathrm{~g} \mathrm{~L}^{-}\right. \\
\text {1) }\end{array}$ & $<1.0$ & $<1.0$ & 12 & \multirow[t]{2}{*}{ Ile $\left(\mu \mathrm{mol} \mathrm{mL}{ }^{-1}\right)$} & \multirow[t]{2}{*}{$69.5 \pm 18$} & \multirow[t]{2}{*}{$47.9 \pm 8.9$} \\
\hline $\mathrm{Na}\left(\mathrm{mg} \mathrm{L}^{-1}\right)$ & 1.412 & 268.6 & 805 & & & \\
\hline$K\left(\mathrm{mg} \mathrm{L}^{-1}\right)$ & 38.00 & 38.3 & 1650 & \multirow{2}{*}{$\begin{array}{l}\text { Phe }(\mu \mathrm{mol} \mathrm{mL}- \\
\text { 1) }\end{array}$} & \multirow[t]{2}{*}{$77.9 \pm 22.2$} & \multirow[t]{2}{*}{$25 \pm 5.8$} \\
\hline $\mathrm{Ca}\left(\mathrm{mg} \mathrm{L}^{-1}\right)$ & 1.170 & 43 & 819 & & & \\
\hline $\mathrm{Mg}\left(\mathrm{mg} \mathrm{L}^{-1}\right)$ & 2.875 & 32.45 & 131 & \multirow{2}{*}{$\begin{array}{l}\text { His }\left(\mu \mathrm{mol} \mathrm{mL}{ }^{-}\right. \\
\text {1) }\end{array}$} & \multirow[t]{2}{*}{$72.5 \pm 15.5$} & \multirow[t]{2}{*}{$17.89 \pm 6.5$} \\
\hline $\mathrm{Fe}\left(\mathrm{mg} \mathrm{L}^{-1}\right)$ & - & 3 & - & & & \\
\hline $\mathrm{NH}_{4}\left(\mathrm{mg} \mathrm{L}^{-1}\right)$ & 1.412 & 5.85 & 217 & \multirow{2}{*}{$\begin{array}{l}\text { Trp }(\mu \mathrm{mol} \mathrm{mL}- \\
\text { 1) }\end{array}$} & \multirow[t]{2}{*}{$49.1 \pm 17.6$} & \multirow[t]{2}{*}{$17.5 \pm 8.7$} \\
\hline $\mathrm{NO}_{3}\left(\mathrm{mg} \mathrm{L}^{-1}\right)$ & - & 16.4 & - & & & \\
\hline$F\left(\mathrm{mg} \mathrm{L}^{-1}\right)$ & 25.057 & - & - & \multirow{2}{*}{$\begin{array}{l}\text { Lys }\left(\mu \mathrm{mol} \mathrm{mL} \mathrm{L}^{-}\right. \\
\left.{ }^{1}\right)\end{array}$} & \multirow[t]{2}{*}{$64.8 \pm 12.7$} & \multirow[t]{2}{*}{$100 \pm 15.4$} \\
\hline $\mathrm{Cl}\left(\mathrm{mg} \mathrm{L}^{-1}\right)$ & 36.576 & 87.8 & - & & & \\
\hline $\mathrm{pH}$ & 4.32 & 7.56 & 4.76 & \multirow{2}{*}{$\begin{array}{l}\text { Arg }(\mu \mathrm{mol} \mathrm{mL}- \\
\left.{ }^{1}\right)\end{array}$} & \multirow{2}{*}{$\begin{array}{l}124.8 \pm \\
19.7\end{array}$} & \multirow{2}{*}{$\begin{array}{l}17.35 \pm \\
5.35\end{array}$} \\
\hline $\operatorname{COD}\left(\mathrm{g} \mathrm{L}^{-1}\right)$ & 245.4 & 4.27 & 47.3 & & & \\
\hline
\end{tabular}

According to the organic matter composition, all effluents showed high COD. The COD of CW and CSL were similar to that described in the literature [25-28]. SDW, however, presented lower values for COD in anmmariann tn thn cninntifin litnrnturn [11 $20 \quad 2 n$ l and wnag more similar to beverage wastewater [31]. Loading [MathJax]/jax/output/CommonHTML/fonts/TeX/fontdata.js 
The presence and concentration of $\mathrm{Mg}, \mathrm{Fe}, \mathrm{Na}$, and $\mathrm{K}$ have a significant effect on hydrogen productivity, especially the first two [32]. $\mathrm{Mg}, \mathrm{Na}$, and $\mathrm{K}$ were observed in high concentrations in all wastewaters. The concentration of $\mathrm{Mg}$ observed in SDW, although lower than in CW and CSL, is enough to stimulate biohydrogen production metabolism. Fe was not detected, and its supplementation could enhance the productivity obtained in this study [33-35]. Ca was another cation observed at high concentrations for all the three wastewaters. $\mathrm{Mn}$ and $\mathrm{Cu}$, which are widely recognised as enzymes cofactors, were not identified. Supplementation with $\mathrm{Mn}$ and Cu could be considered in future studies.

CSL and CW showed up as important sources of nitrogen (10.5 and 3.6, respectively), values comparable to other research $[21,36]$. This content is sufficient to support biomass production without the need to supplement with other nitrogen sources, such as yeast extract, meat extract, and ammonium sulphate $[20,37]$, which have a significant impact on the process economy. The amino acid composition of CSL and $\mathrm{CW}$ showed that L-cysteine, a recurring supplement for hydrogen production fermentations $[35,38$, 39], is present in CW and CSL in significant amounts. The presence of methionine, alanine, histidine, and lysine in ranges from 1.0 to $10.0 \mathrm{~g} \mathrm{~L}^{-1}$ may also have a positive impact on biohydrogen production. The synergetic effect of these amino acids with ferric oxide was described to increase the volumetric hydrogen produced 1.3 times $[40,41]$. The higher amino acid concentrations found in this work were methionine and valine for CSL and histidine and arginine for CW. According to Hofer et al. (2018), phenylalanine and isoleucine should be primarily free in the effluents, while arginine, histidine, and lysine are essentially bound in proteins or peptides. Thus, arginine, histidine, and lysine concentrations in $\mathrm{CW}$ may be underestimated.

The initial $\mathrm{pH}$ is relevant for biohydrogen production. The optimum $\mathrm{pH}$ for Clostridium is approximately $6.0[42,43]$, while fermentation is severely impaired under $\mathrm{pH} 4.0$ or over $\mathrm{pH} 12.0$ [12]. Although all the fermentations were adjusted to $\mathrm{pH} 7.0$, it is interesting to consider the amount of alkali necessary to correct the $\mathrm{pH}$ of CSL and CW. Despite the chemical composition of SDW not being remarkably interesting in terms of carbohydrates, cations, and anions, it could be used as a dilutant to facilitate $\mathrm{pH}$ correction.

Clostridium butyricum identification

According to the BLAST analysis and phylogenetic tree (Fig. 1), the isolate strain was identified as Clostridium butyricum with $99 \%$ similarity. The phylogenetic tree constructed with the neighbour-joining method revealed that the $C$. butyricum was included in the same subcluster with $C$. saccharoperbutylacetonicum, C. puniceum, C. saccharobutylicum, C. chromiireducens, C. diolis, $C$. beijerinckii, and C. neonatale.

\section{Variable Selection, Optimisation, And Mathematical Models}

The Pareto diagram (Figure not shown) showed that among the five variables tested, only \%CSL and fermentation time significantly affected the production of hydrogen $(p \leq 0.05)$ for the isolated strain. For Clostridium beijerinckii, CW, \%CSL, and fermentation time were significant ( $\leq \leq 0.05)$. Previous works 
demonstrate that the concentration of CSL, whey, and the fermentation time affect hydrogen production via dark fermentation $[22,27]$. The inoculum rate was not significant $(p \leq 0.05)$, which may have been because large inoculum volumes were tested; an inoculum rate of $10 \%$ was then used for all experiments.

It was expected that due to its large amount sugar the expired soft drink would be significant in all tests performed. However, this variable was not significant $(p \leq 0.05)$. Soft drinks were added to the medium in a concentration of $20 \%$, and even though it was diluted, the antimicrobial properties of the finished product were still outstanding. According to Kregiel [44], soft drinks contain chemical preservatives and acids that play an important role in avoiding microbial growth. Sorbates and benzoates present in the soft drink act together to enhance antimicrobial effectiveness against bacteria and other microorganisms. Notwithstanding, the author still emphasises that this combination causes the inhibition of amino acid uptake and destroys the internal proton level of microbial cells.

On the other hand, the contour surface graphs (Figs. 2A and 2B) showed that the optimal hydrogen production is reached with $12-14 \% \mathrm{CSL}$, at $37.5-48 \mathrm{~h}$ time of fermentation and $38.5-45 \% \mathrm{CW}$ for Clostridium beijerinckii. In the case of Clostridium butyricum, the optimum hydrogen production was 10$14 \%$ CSL and 36-52 h (Fig. 2C).

\section{Mathematical Models}

Two second-order polynomial models that simulate the production of biohydrogen under the conditions described are presented in equations 2 (Clostridium beijerinckii) and 3 (Clostridium butyricum). The mathematical models presented an $\mathrm{R}^{2}$ of 0.95 and 0.895 for equations 2 and 3 , respectively, which indicates that $95 \%$ and $89.5 \%$ of hydrogen production is governed by the variables selected. According to Hye et al. and Martinez-Burgos et al. [23, 45], mathematical models with $\mathrm{R}^{2} \geq 80 \%$ are adequate to simulate the behaviour of the response variables.

$H_{2}=11.96+3.7 C S L+2.58 t-1.29 C S L^{2}-2.74 t^{2}+2.54 C S L * t+0.13 C W$ (Eq. 2)

$H_{2}=20.76+4.68 C S L+5.13 t-4.76 C S L^{2}$ (Eq. 3)

According to the mathematical model (Eq. 2), the optimal conditions for the production of biohydrogen with Clostridium beijerinckii were $\mathrm{CSL}=12 \%, \mathrm{t}=48 \mathrm{~h}$, and $\mathrm{CW}=40 \%$. The experimental and predicted hydrogen volumes at the optimum condition were $18.5 \pm 1.68 \mathrm{~mL}$ and $16.87 \mathrm{~mL}$, respectively. In the case of Clostridium butyricum, the conditions were CSL $=12 \%$ and $t=48 \mathrm{~h}$. The experimental and predicted biohydrogen volumes for this strains were $27.4 \pm 1.84 \mathrm{~mL}$ and $26.5 \mathrm{~mL}$, respectively. In both cases, there was no significant difference between the experimental and modelled volumes.

\section{Evaluation Of Biohydrogen Production Under Optimum Conditions}

Under the optimum conditions selected, the maximum volume of hydrogen produced by the bacteria Clostridium butyricum and Clostridium beijerinckii was $27.47 \pm 1.8 \mathrm{~mL}$ and $19.05 \pm 0.70 \mathrm{~mL}$, respectively 
production of hydrogen did not improve so the fermentation process could be stopped at this time. It is noteworthy that the yield of hydrogen produced with $C$. butyricum $\left(310 \mathrm{~mL} \mathrm{H}_{2} / \mathrm{g}\right.$ coD removed ) was approximately $40 \%$ greater than that obtained as C. beijerinckii $(235 \mathrm{~mL} \mathrm{H} / \mathrm{g}$ coD removed). These yields are higher than those reported in other studies that had been supplemented with some compounds. [46] supplemented the effluent with $\mathrm{Fe}^{2+}$, peptone, and $\mathrm{Na}_{2} \mathrm{HPO}_{4}+2 \mathrm{H}_{2} \mathrm{O}$ and obtained a yield of $215 \mathrm{~mL} \mathrm{H} / \mathrm{g}$ $\mathrm{COD}_{\text {removed }}$. Zampol et al. [47] supplemented the medium with $\mathrm{KH}_{2} \mathrm{PO}_{4}, \mathrm{~K}_{2} \mathrm{HPO}_{4}, \mathrm{MgSO}_{4}, \mathrm{NaCl}, \mathrm{CaCl}_{2}$, yeast extract, iron citrate and reported a maximum yield of $137 \mathrm{~mL} \mathrm{H} / \mathrm{g}$ COD removed. Ozkan et al. [48] supplemented the effluent with Basal medium and obtained a yield of $115.6 \mathrm{~mL} \mathrm{H} / \mathrm{g} \mathrm{COD}$ removed.

On the other hand, it was observed that for both microorganisms studied no significant difference ( $\mathrm{p}$ value $\leq 0.05$ ) between the hydrogen production between the cysteine-HCl-supplemented and not supplemented media (Fig. 3B). This indicates that the CSL can supply the amino acid demands of the microorganisms and its use could decrease the costs of the culture media destined for the production of hydrogen via biological production.

In both cases, the main carbon sources such as glucose and fructose were consumed almost completely (Figs. 3C and 3D). In addition, it was observed that the microorganisms could use lactic acid as an alternative carbon source. The metabolites produced in the fermentation were mainly butyric and acetic acid, with predominance of the first. It is noteworthy that the production of the latter was greater with $C$. butyricum which could be an explanation of the greater production of hydrogen with this strain, acetate generates $2 \times$ more $\mathrm{H}_{2}$ than butyrate [49]. Also, it was observed that part of the acetic acid and the butyric acid produced was consumed in the same fermentation, as these can also be used as alternative carbon sources. $[23,50]$ showed that acetic and butyric acid can be used as carbon sources by some microorganisms in dark fermentation. Likewise, both microorganisms produced traces of propionic acid. However, the production of this metabolite is not desirable in dark fermentation because stoichiometrically hydrogen is needed for its production $[8,9]$.

The amino acid profile during the $C$. butyricum fermentation (Fig. 3E) show a slight consumption in the amino acids cysteine and threonine available in the medium. The methionine and valine concentrations were maintained above the concentration of the other amino acids, and most of them showed similar concentrations in the beginning and end of the fermentation time. Sharma and Melkania [40,41] tested the effect of methionine, alanine, histidine, cysteine and lysine in the production of hydrogen by co-culture of E. coli and Enterobacter aerogenes in municipal solid waste. The best productivities were with the addition of alanine and cysteine, and the butyrate concentration was increased during the fermentation, favouring the butyrate hydrogenogenic pathway. A similar increase in the butyric acid occurred in this work, possibly explaining why cysteine was consumed. Several authors indicate that cysteine supplementation in the medium enhance biohydrogen production $[34,35,38,39]$. The bioavailability of each amino acid also indicates which can be used and directed for the metabolic pathways. Hofer et al. [24] found that the content of threonine, tryptophan, and phenylalanine were more than $60 \%$ free in CSL, 
while cysteine and valine were around $35 \%$ free in the solution. The cysteine and threonine found in this work were also likely available for $C$. butyricum dark fermentation.

\section{Conclusion}

Biohydrogen is a promising alternative to the fossil fuels since it emits no greenhouse gases and its production from agro-industrial wastes significantly reduces the production costs. This work showed that the species Clostridium beijerinckii ATCC 8260 and the identified strain Clostridium butyricum DEBB-B348 are capable of producing hydrogen from soft drink wastewater, corn steep liquor, and cheese whey. The mathematical models reached by the RCCD showed an $R^{2}$ of 0.950 and 0.895 , with fermentation time and corn steep liquor being the most significant factors. The carbohydrate consumption and organic acid formation kinetics also indicate that the butyrate metabolic pathway was favoured. The maximum hydrogen volume production was $18.5 \pm 1.68 \mathrm{~mL}$ and $27.4 \pm 1.84 \mathrm{~m} \mathrm{~L}$ for $C$. beijerinckii and $C$. butyricum, respectively. The results show an interesting alternative to the production of hydrogen through dark fermentation, giving a sustainable alternative for agro-industrial waste disposal and generating an ecofriendly fuel.

\section{Declarations}

Funding: National Council of Technological and Scientific Development (CNPq) and Coordination for the Improvement of Higher Education Personnel (CAPES), Brazil.

Conflicts of interest: There are no conflicts of interest.

\section{References}

1. Martinez-Burgos WJ, de Souza Candeo E, Pedroni Medeiros AB et al (2021) Hydrogen: Current advances and patented technologies of its renewable production. J Clean Prod 286:. https://doi.org/10.1016/j.jclepro.2020.124970

2. Junior JR do, Torres N, Medeiro LZ ABP, et al (2021) Enhancement of biohydrogen production in industrial wastewaters with vinasse pond consortium using lignin-mediated iron nanoparticles. 113. https://doi.org/10.1016/j.jijhydene.2021.06.009

3. Kossalbayev BD, Tomo T, Zayadan BK et al (2020) Determination of the potential of cyanobacterial strains for hydrogen production. Int J Hydrogen Energy 45:2627-2639.

https://doi.org/10.1016/j.jjhydene.2019.11.164

4. Anwar M, Lou S, Chen L et al (2019) Recent advancement and strategy on bio-hydrogen production from photosynthetic microalgae. Bioresour Technol 292:121972.

https://doi.org/10.1016/j.biortech.2019.121972

5. Pan C, Fan Y, Zhao P, Hou H (2008) Fermentative hydrogen production by the newly isolated Clostridium beiierinckii Fann3. Int J Hvdrocen Enerav 33:5383-5391.

Loading [MathJax]/jax/output/CommonHTML/fonts/TeX/fontdata.js

Page 11/18 
https://doi.org/10.1016/j.ijhydene.2008.05.037

6. Nath K, Das D (2004) Improvement of fermentative hydrogen production: various approaches. Appl Microbiol Biotechnol 65:520-529. https://doi.org/10.1007/s00253-004-1644-0

7. Rosa D, Medeiros ABP, Martinez-Burgos WJ et al (2020) Biological Hydrogen Production from Palm Oil Mill Effluent (POME) by Anaerobic Consortia and Clostridium beijerinckii Drielly. J ofBiotechnology. https://doi.org/10.1016/j.jbiotec.2020.06.015

8. Lin PY, Whang LM, Wu YR et al (2007) Biological hydrogen production of the genus Clostridium: Metabolic study and mathematical model simulation. Int J Hydrogen Energy 32:1728-1735. https://doi.org/10.1016/j.ijhydene.2006.12.009

9. Martinez-Burgos WJ, Sydney EB, Brar SK et al (2019) The effect of hydrolysis and sterilization in biohydrogen production from cassava processing wastewater medium using anaerobic bacterial consortia. Int J Hydrogen Energy 44:25551-25564. https://doi.org/10.1016/j.jijhydene.2019.08.085

10. Wu H, Wang C, Chen P et al (2017) Effects of $\mathrm{pH}$ and ferrous iron on the coproduction of butanol and hydrogen by Clostridium beijerinckii IB4. Int J Hydrogen Energy 42:6547-6555. https://doi.org/10.1016/j.ijhydene.2017.02.094

11. Kumar G, Bakonyi P, Sivagurunathan $P$ et al (2015) Enhanced biohydrogen production from beverage industrial wastewater using external nitrogen sources and bioaugmentation with facultative anaerobic strains. J Biosci Bioeng 120:155-160. https://doi.org/10.1016/j.jbiosc.2014.12.011

12. Prabakar D, Manimudi VT, Suvetha KS et al (2018) Advanced biohydrogen production using pretreated industrial waste: Outlook and prospects. Renew Sustain Energy Rev 96:306-324. https://doi.org/10.1016/j.rser.2018.08.006

13. American-Public-Health-Association (1992) Standard Methods for the Examination of Water and Wastewater., 18th ed. Washington DC, APHA, AWWA, WWCF

14. Bittencourt E, Larroche $C$, Cristine A et al (2014) Economic process to produce biohydrogen and volatile fatty acids by a mixed culture using vinasse from sugarcane ethanol industry as nutrient source. Bioresour Technol 159:380-386. https://doi.org/10.1016/j.biortech.2014.02.042

15. Kumar S, Stecher G, Li M et al (2018) MEGA X: Molecular evolutionary genetics analysis across computing platforms. Mol Biol Evol 35:1547-1549. https://doi.org/10.1093/molbev/msy096

16. Cavalli-Sforza LL, Edwards AW (1967) Phylogenetic analysis. Models and estimation procedures. Am J Hum Genet 19:233-257

17. Kluge AG, Farris JS (2011) Society of Systematic Biologists Quantitative Phyletics and the Evolution of Anurans QUANTITATIVE PHYLETICS AND THE EVOLUTION OF ANURANS. Society 18:1-32

18. J F (1985) Confidence Limits on Phylogenies: An Approach Using the Bootstrap Author (s): Joseph Felsenstein Stable URL : http://www.jstor.org/stable/2408678. Evolution (N Y) 39:783-791

19. Balch WE, Fox GE, Magrum LJ et al (1979) Methanogens: Reevaluation of a Unique Biological Group. Microbiol Rev 43:260-296 
20. Alvarado-Cuevas Z, Acevedo LGO, Salas JTO, León-Rodríguez A De (2013) Nitrogen sources impact hydrogen production by Escherichia coli using cheese whey as substrate. N Biotechnol 00:2-7. https://doi.org/10.1016/j.nbt.2013.03.002

21. Yasmin A, Sadiq Butt M, Sameen A, Shahid M (2013) Physicochemical and amino acid profiling of cheese whey. Pakistan J Nutr 12:455-459. https://doi.org/10.3923/pjn.2013.455.459

22. Martinez-Burgos WJ, Sydney EB, de Paula DR et al (2021) Hydrogen production by dark fermentation using a new low-cost culture medium composed of corn steep liquor and cassava processing water: Process optimization and scale-up. Bioresour Technol 320:124370. https://doi.org/10.1016/j.biortech.2020.124370

23. Martinez-Burgos WJ, Sydney EB, de Paula DR et al (2020) Biohydrogen production in cassava processing wastewater using microbial consortia: Process optimization and kinetic analysis of the microbial community. Bioresour Technol 309:123331.

https://doi.org/10.1016/j.biortech.2020.123331

24. Hofer A, Hauer S, Kroll P et al (2018) In-depth characterization of the raw material corn steep liquor and its bioavailability in bioprocesses of Penicillium chrysogenum. Process Biochem 1-33. https://doi.org/10.1016/j.procbio.2018.04.008

25. Farizoglu B, Keskinler B, Yildiz E, Nuhoglu A (2004) Cheese whey treatment performance of an aerobic jet loop membrane bioreactor. Process Biochem 39:2283-2291. https://doi.org/10.1016/j.procbio.2003.11.028

26. Zhang W, Xie Q, Rouse JD et al (2009) Treatment of high-strength corn steep liquor using cultivated Polyvinyl alcohol gel beads in an anaerobic fluidized-bed reactor. J Biosci Bioeng 107:49-53. https://doi.org/10.1016/j.jbiosc.2008.11.002

27. D囚bowski M, Korzeniewska E, Filipkowska Z et al (2014) Possibility of hydrogen production during cheese whey fermentation process by different strains of psychrophilic bacteria. Int J Hydrogen Energy 39:1972-1978. https://doi.org/10.1016/j.ijhydene.2013.11.082

28. Ghimire A, Luongo V, Frunzo L et al (2017) Continuous biohydrogen production by thermophilic dark fermentation of cheese whey: Use of buffalo manure as buffering agent. Int $\mathrm{J}$ Hydrogen Energy 42:4861-4869. https://doi.org/10.1016/j.jjhydene.2016.11.185

29. Wickham R, Xie S, Galway B et al (2018) Anaerobic digestion of soft drink beverage waste and sewage sludge. Bioresour Technol. https://doi.org/10.1016/j.biortech.2018.04.046

30. Peixoto G, Saavedra NK, Varesche MBA, Zaiat M (2011) Hydrogen production from soft-drink wastewater in an upflow anaerobic packed-bed reactor. Int J Hydrogen Energy 36:8953-8966. https://doi.org/10.1016/j.jhydene.2011.05.014

31. Lay CH, Vo TP, Lin PY et al (2019) Anaerobic hydrogen and methane production from low-strength beverage wastewater. Int J Hydrogen Energy 44:14351-14361. https://doi.org/10.1016/j.jhydene.2019.03.165

32. Aly SS, Imai T, Hassouna MS et al (2017) Identification of factors that accelerate hydrogen 
Hydrogen Energy 1-14. https://doi.org/10.1016/j.jhydene.2017.08.171

33. Yang G, Wang J (2018) Various additives for improving dark fermentative hydrogen production: A review. Renew Sustain Energy Rev 95:130-146. https://doi.org/10.1016/j.rser.2018.07.029

34. Bao MD, Su HJ, Tan TW (2013) Dark fermentative bio-hydrogen production: Effects of substrate pretreatment and addition of metal ions or $L$-cysteine. Fuel 112:38-44.

https://doi.org/10.1016/j.fuel.2013.04.063

35. Zhao X, Xing D, Liu B et al (2012) The effects of metal ions and L-cysteine on hyd A gene expression and hydrogen production by Clostridium beijerinckii. Int J Hydrogen Energy 37:13711-13717. https://doi.org/10.1016/j.ijhydene.2012.02.144

36. Yang T, Rao Z, Zhang X, Xu M (2013) Effects of corn steep liquor on production of 2, 3-butanediol and acetoin by Bacillus subtilis. Process Biochem 70:20-28.

https://doi.org/10.1016/j.procbio.2013.07.027

37. Maddipati P, Atiyeh HK, Bellmer DD, Huhnke RL (2011) Ethanol production from syngas by Clostridium strain $\mathrm{P} 11$ using corn steep liquor as a nutrient replacement to yeast extract. Bioresour Technol 102:6494-6501. https://doi.org/10.1016/j.biortech.2011.03.047

38. Yuan Z, Yang H, Zhi X, Shen J (2008) Enhancement effect of I-cysteine on dark fermentative hydrogen production. Int J Hydrogen Energy 33:6535-6540. https://doi.org/10.1016/j.ijhydene.2008.07.065

39. Qu YY, Guo WQ, Ding J, Ren NQ (2012) Effect of L-cysteine on continuous fermentative hydrogen production. Appl Mech Mater 178-181:406-410. https://doi.org/10.4028/www.scientific.net/AMM.178-181.406

40. Sharma P, Melkania U (2018) Enhancement effect of amino acids on hydrogen production from organic fraction of municipal solid waste using co-culture of Escherichia coli and Enterobacter aerogenes. Energy Convers Manag 163:260-267. https://doi.org/10.1016/j.enconman.2018.02.072

41. Sharma P, Melkania U (2018) Synergic effect of various amino acids and ferric oxide on hydrogen production. Int J Hydrogen Energy 43:15843-15856. https://doi.org/10.1016/j.ijhydene.2018.06.174

42. Ferchichi M, Crabbe E, Gil GH et al (2005) Influence of initial pH on hydrogen production from cheese whey. J Biotechnol 120:402-409. https://doi.org/10.1016/j.jbiotec.2005.05.017

43. Skonieczny MT, Yargeau V (2009) Biohydrogen production from wastewater by Clostridium beijerinckii: Effect of pH and substrate concentration. Int J Hydrogen Energy 34:3288-3294. https://doi.org/10.1016/j.jhydene.2009.01.044

44. Kregiel D (2015) Health safety of soft drinks: Contents, containers, and microorganisms. Biomed Res Int 2015:. https://doi.org/10.1155/2015/128697

45. Hye J, Lee DS, Park D et al (2008) Optimization of key process variables for enhanced hydrogen production by Enterobacter aerogenes using statistical methods. Bioresour Technol 99:2061-2066. https://doi.org/10.1016/j.biortech.2007.04.027

46. Krishnan S, Singh L, Sakinah M et al (2016) Process enhancement of hydrogen and methane Loading [MathJax]/jax/output/CommonHTML/fonts/TeX/fontdata.js e thermophilic and mesophilic fermentation. Int 
J Hydrogen Energy 41:12888-12898. https://doi.org/10.1016/j.ijhydene.2016.05.037

47. Zampol C, Bernadete M, Varesche A, Edson S (2015) Sequential fermentative and phototrophic system for hydrogen production: An approach for Brazilian alcohol distillery wastewater. Int $\mathrm{J}$ Hydrogen Energy 40:9642-9655. https://doi.org/10.1016/j.jhydene.2015.06.003

48. Ozkan L, Erguder TH, Demirer GN (2011) Effects of pretreatment methods on solubilization of beetpulp and bio-hydrogen production yield. Int J Hydrogen Energy 36:382-389. https://doi.org/10.1016/j.ijhydene.2010.10.006

49. Sydney EB, Duarte ER, Martinez-Burgos WJ et al (2020) Development of short chain fatty acid-based artificial neuron network tools applied to biohydrogen production. Int Jorurnal Hydrog Energy 5:5175-5181. https://doi.org/10.1016/j.ijhydene.2019.10.128

50. Matsumoto M, Nishimura Y (2007) Hydrogen Production by Fermentation Using Acetic Acid and Lactic Acid. J Biosci Bioeng 103:236-241. https://doi.org/10.1263/jbb.103.236

\section{Figures}




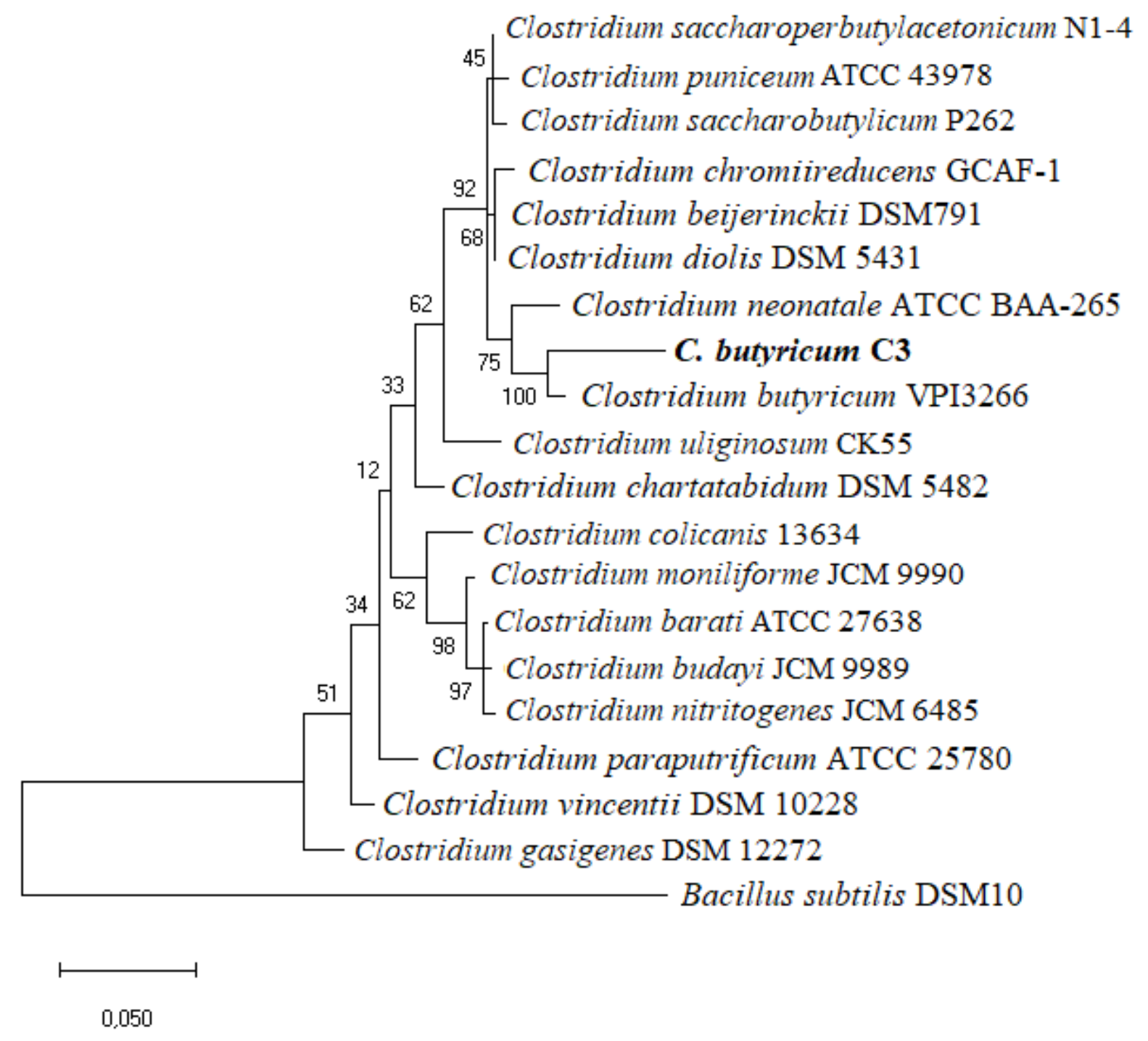

Figure 1

Maximum-likelihood tree based on 16s rRNA gene sequences showing the phylogenetic relationships. Bootstrap values (\%) based on 1000 replications are shown at branch points. The substitution model used was kimura 2-parameter model bar, with $0.05 \%$ sequence divergence. 

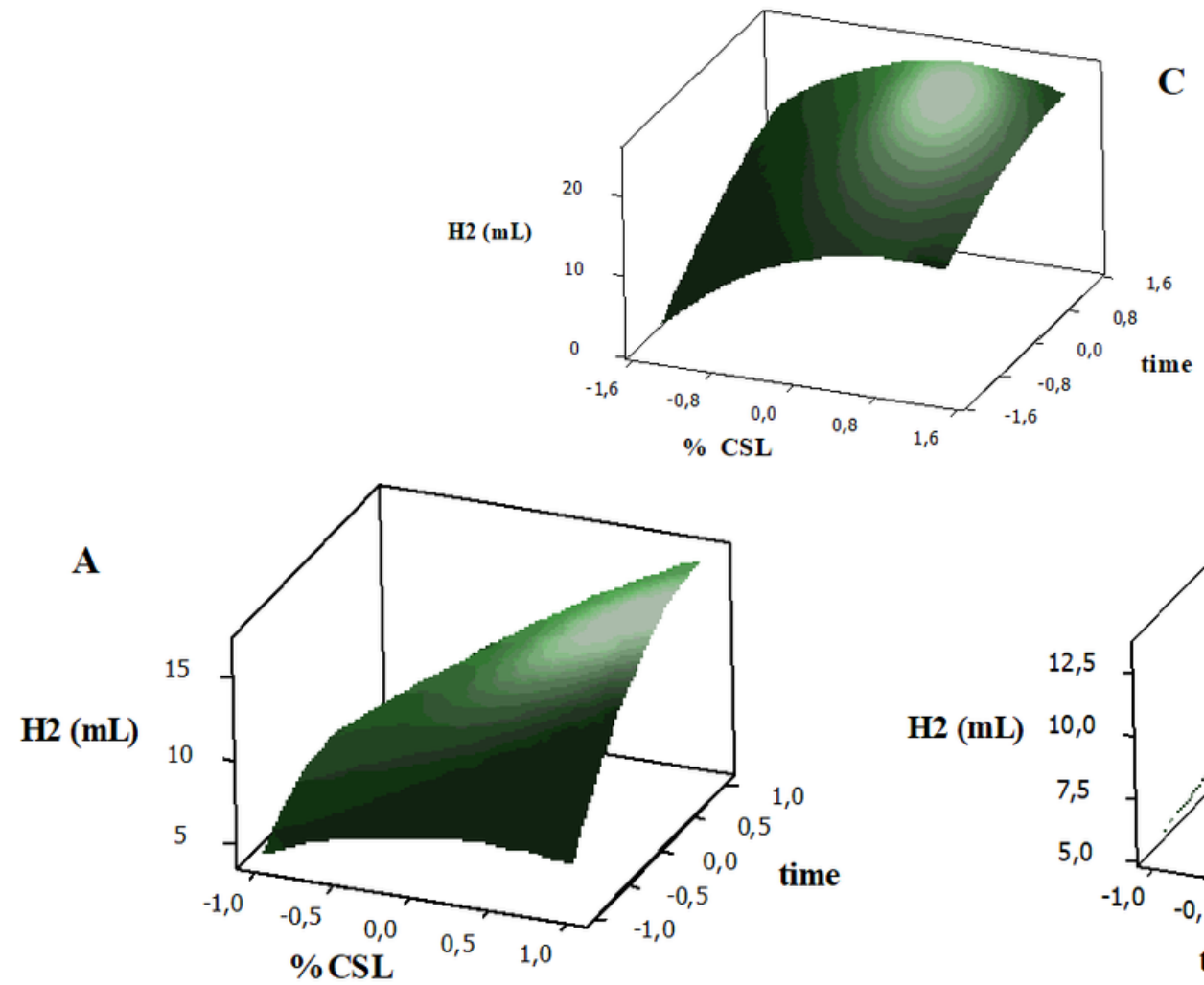

B

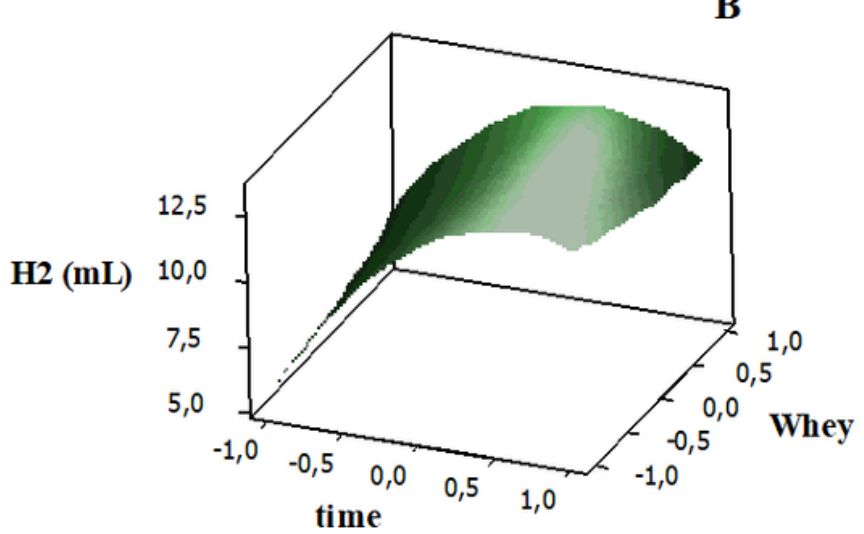

\section{Figure 2}

Response surfaces for bio hydrogen production using $C$. beijerinckii and $C$. butyricum. A and B) C. beijerinckii. C) C. butyricum. 

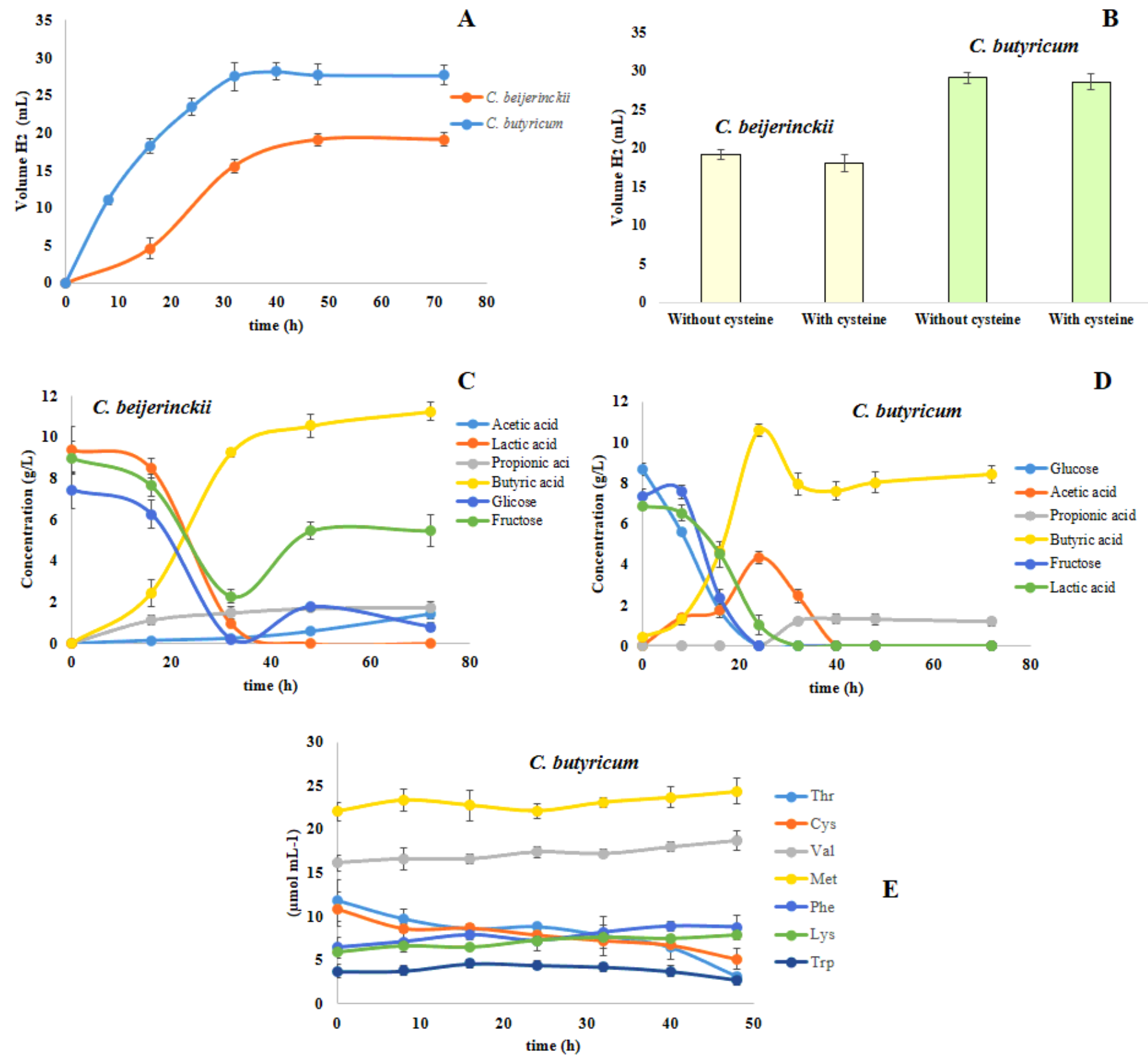

Figure 3

Behaviour of substrate consumption and metabolite production in dark fermentation 